\title{
Typology of Kimbeere Relative Clauses in Kimbeere
}

\author{
Peter Kinyua Muriungi \\ Tharaka University College \\ Nancy Mbandi Mutange \\ PhD Student, Chuka University, Kenya
}

\begin{abstract}
In this paper we explore the typology of Kimbeere- a Kenya Bantu language. The paper demonstrates that like in other languages, Kimbere has different types of relative clauses namely restrictive, non-restrictive, direct, indirect, appositive, headless among other. Kimbere also has a type of relative clause called ingi relative. The paper is descriptive and contributes typological data which is crucial for drawing principles and parameters in natural language.
\end{abstract}

Key Words: Relative clause, direct, indirect, headless, restrictive, typology

DOI: $10.7176 / J L L L / 62-09$

Publication date: November $30^{\text {th }} 2019$

\section{Introduction}

In this paper we present the types of Kimbeere relative clauses. The paper has the following sections: In section 2 we examine the typology of Kimbeere language. In section 3 are types of Kimbeere relative clauses while section 4 and 5 contain findings and conclusion of this study respectively.

\section{Brief Introduction to Kimbeere}

It is necessary to point out that Kimbeere is a head first/verb-initial language. Consider the phrases in (1) below.

1).a) Twagũrire gĩtĩ kĩnene. $\quad$ (Noun phrase)

Tũ- a- gũr- ir- e- gĩtĩ kĩ-nene

1pl- PST- buy- PERF- FV 7.chair 7-big

'We bought a big chair'

b) Ina wega ũbewe kĩbeo. (Verb phrase) 
I- na wega ũ- be- w- e kĩbeo

2sg- sing well 2sg- give- PASS- FV 7.present

'Sing well to win/be given a present'

c) Mainire wega mũno.

(Adverb phrase)

M- a- in- ir- e wega mũno

3pl- PST- sing- PERF- FV well very

'They sang very well'

In (1.a) the noun 'gĩtĩ' (chair) is modified by the adjective 'kĩnene' (big). It is evident that 'gĩti'(chair) which is the head of the noun phrase comes before the modifier, 'kinene'(big). Similarly, the verb 'ina' (sing) and the adverb 'wega' (well) comes before the adverb 'wega' (well) and the adverb 'mũno' (very) in the verb phrase (1.b) and adverb phrase (1.c) respectively. Apparently this contrasts with English structures that have the modifier preceding or following the modified element. However Kiswahili happens to behave like Kimbeere in this aspect. Consider structures (2) and (3) for comparison.

(2) We bought $a$ big chair

(English)

Adj

Noun

(3) $\mathrm{Tu}$ li- nunua kiti

We- PST- buy Noun

kikubwa

(Kiswahili)

We bought chair

Adj

'We bought a big chair'

According to Finegan (2008) verb-initial languages place relative clauses after head nouns. From examples (1a-c) and (3) it is evident that in Kimbeere and Kiswhili, heads appear before their modifiers, therefore they are head first languages.

\section{Types of Kimbeere Relative Clauses}

Kimbeere has different types of relative clauses as discussed below.

\subsection{Restrictive Relative Clauses}

Just like their English counterparts, Kimbeere restrictive relative clauses restrict the noun referred to. The relative clause is introduced by a relative marker '-rĩa' which is attached to the noun prefix that agrees in number and class with the head noun. Consider sentence (4). 
Note that data in all analysis sections is presented in the order: Kimbeere sentence, single words, morphology, English translation.

(4) Iratũ irĩa Kagendo arabeere Njeri nĩ nene.

Iratũ i-rĩa Kagendo a-ra- be- er- e Njeri

8.Shoes $\quad$ 8-REL 1.Kagendo $\quad$ sm $_{1}$-PST-give-PERF- FV1 Njeri

nĩ nene

FOC big

'The shoes which Kagendo gave Njeri are big'

In this example, 'iratũ' (shoes) is the head noun. Note how the 'i-' (object prefix) in 'iratũ' agrees with the 'i-' attached to '-rĩa' in 'irĩa', the relative marker. The clause 'irĩa Kagendo arabeere Njeri' (which Kagendo gave Njeri) restricts the shoes (iratũ) to a particular category of shoes that is the ones Kagendo gave Njeri and not any other. More examples are listed in (5) to (8).

Gĩkombe kĩrĩa natũmĩre nîkĩaũrire.

Gĩkombe kĩ-rĩa na- tũm- ĩr- e nĩ- kĩ-a- ũr-

7.Cup 7-REL 1sg- use- Appl- FV FOC 7-PST-lose-

ir- $\quad \mathrm{e}$

PERF FV

'The cup which I used got lost'

(6) Nduthi ĩria mama aragũrire nĩ ndaca mũno.

Nduthi ĩ-rĩa mama a- ra- gũr- ir- $\mathrm{e}$ nĩ

9.Motorcycle 9-REL 1.uncle $\mathrm{sm}_{1-}$ PST- buy- Compl-FV FOC

n- daca mũno

om9 long very

'The motocycle which my uncle bought is very long'

(7) Kĩondo kĩrĩa cũcũ aratuma nĩ kĩgemie wega.

Kĩondo kĩ-rĩa $c \tilde{u} c \tilde{u} \quad a$ - ra-tuma nĩ kĩ-gemi-

7.Basket 7-REL 1.grandmother $\mathrm{sm}_{1^{-}}$Pres-weave FOC 7-decorate-

-e wega

-FV well

'The basket which grandmother is weaving is well decorated.' 
(8) Ĩcembe rĩrĩa Karani arathondekire nĩ rĩaunĩka.

Ĩcembe rĩ-rĩa Karania- ra- thondek- ir- $e$

5.Jembe 5-REL 1.Karani $\mathrm{sm}_{1-}{ }^{-}$PST- fix- PERF- FV

nĩ rĩ a unĩk- a

FOC om5 pr- break- FV

'The jembe which Karani fixed has broken.'

In (5) to (8) the head nouns 'gîkombe', 'nduthi', 'kĩondo' and 'ĩcembe' happen to be the objects of the verbs 'tümĩre', 'gũrire', 'tuma' and 'thondekire' respectively. The restrictive relatives' classification was instrumental in illustrating how Kimbeere language can restrict the identity of common nouns using relative clauses.

\subsection{Appositive Relative Clauses}

This type of relative clauses gives additional information about the head noun. An appositive is separated from the rest of the sentence using commas.

(9) Nyaga, ũrĩa wendagia ĩria, nĩ mũũku.

Nyaga, $\quad \tilde{u}$-rĩa $\tilde{u}$ - end- ag- $i_{-} \quad a \quad$ iria, nĩ

1.Nyaga, 1-REL sm ${ }^{-}$sell HAB- PROG-FV- 5.milk FOC

mũ- $\quad$ ũk- $\quad$ u

$\mathrm{sm}_{1-}$ come- FV

'Nyaga, who sells milk, is coming.'

The part that is outside the commas in (9)forms the main clause. The part in italics is the relative clause. There are more examples in (10) to (12).

(10) Muthoni, ũrĩa Ngari arabikirie, nĩ mũrũaru.

Mũthoni, $\quad \tilde{u}$-rĩa Ngari a-ra- bik-ir- $i-\quad e$,

1.Muthoni, 1-REL 1.Ngari-sm 1 -PST-marry-PERF PART FV,

nĩ mũ- rũaru

FOC om $_{1-}^{-}$sick.

'Muthoni, who Ngari married, is sick'

(11) Wacuka, ũrĩa tũrabũũrĩre thimũ , nũthiũre Thika.

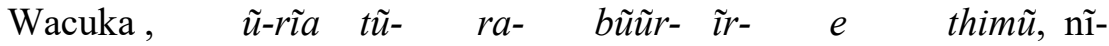


1.Wacuka, 1-REL 1pl- PST- call Appl- FV 9.phon FOC

-ũ- thi- ĩr- e Thika

-sm1- go- Appl- FV Thika

'Wacuka, who we called on phone, went to Thika'

(12) Mũthuri, ũrĩa ũrakethirie Wacira, nĩ mamawe.

Mũthuri, $\quad \tilde{u}$-rĩa $\tilde{u}$ - $\quad r a-\quad k e t h-i r-\quad i-\quad e$

1.Man, $1 \quad$ 1-REL $\mathrm{sm}_{1} \quad$ PST greet- PERF- PART FV

Wacira, nĩ mama- we

1.Wacira, FOC 1.uncle- his

'The man, who greeted Wachira, is his uncle'

Evidently, the relative clauses in italics (10) to (12) only give additional information about the head nouns, Muthoni, Wacuka and Mũthuri, on their left.

For Swedish appositives, says Vries (2002), a definite marker is obligatory on the antecedent if it is preceded by a demonstrative contrary to the situation in restrictive relative constructions. The normal definite marker in Swedish is a suffix for example hus-et 'the house'. A 'free determiner' can be added if an adjective precedes the noun: detroda huset 'the red house-the', or if the interpretation is demonstrative: de huset 'that house-the'. However, such markers are not present in Kimbeere. Consider construction (13) for comparison with (10) to (12).

Det huset som han talade om ligger dar borta
The house-the that he talked about is over there
(Vries, 2002)

This classification of appositive relative clauses is relevant in that it demonstrates how relative clauses can be used to give more information on proper and common nouns in Kimbeere.

\subsection{Direct Relative Clauses}

A direct relative clause resembles a restrictive relative clause. If the clause is removed, meaning is altered. The difference between a direct and an indirect relative clause is that the 
head noun in the direct relative clause corresponds to the subject of the verb. The relative clause in (14) illustrates this.

(14) Ngũkũ ĩria yarekia ĩtumbĩ nĩ yathiĩ.

Ngũkũ ĩ-rĩa ya- reki- a ĩtumbĩ nĩ i-a- thiĩ.

9.Hen 9-REL om9- lay- FV egg FOC-om9-AUX-go.

'The hen which has laid an egg has left'

In (14), 'Ngũkü' is the subject. The direct relatives' classification was key in investigating whether in Kimbeere relative clauses, a head noun can correspond to the subject of the sentence.

\subsection{Indirect Relative Clauses}

In this type, the head noun corresponds to other things other than the subject. That means the head noun can be an object. In (15) \& (16), the head nouns 'müthuri' (the man) and 'mürutwa' (student) are direct and indirect objects respectively.

(15) Mũthuri ũrĩa Njoki akethirie nĩ injinia.

$\begin{array}{lllllll}\text { Mũthuri } & \tilde{u} \text {-rĩa } & \text { Njoki } & a- & \text { kethirie } & \text { nĩ } & \text { injinia. } \\ \text { 1.Obj } & 1-R E L & 1 \text { Subj } & \text { SM1 } & \text { greet } & \text { FOC } & \text { 1.Subj. Compl. } \\ \text { Man } & \text { that } & \text { Njoki } & & \text { greeted } & \text { is } & \text { an engineer. }\end{array}$

'The man that Njoki greeted is an engineer'

(16) Mũrutwa ũrĩa mwarimũ arabeere kĩbeo nĩ mwĩrutĩri.

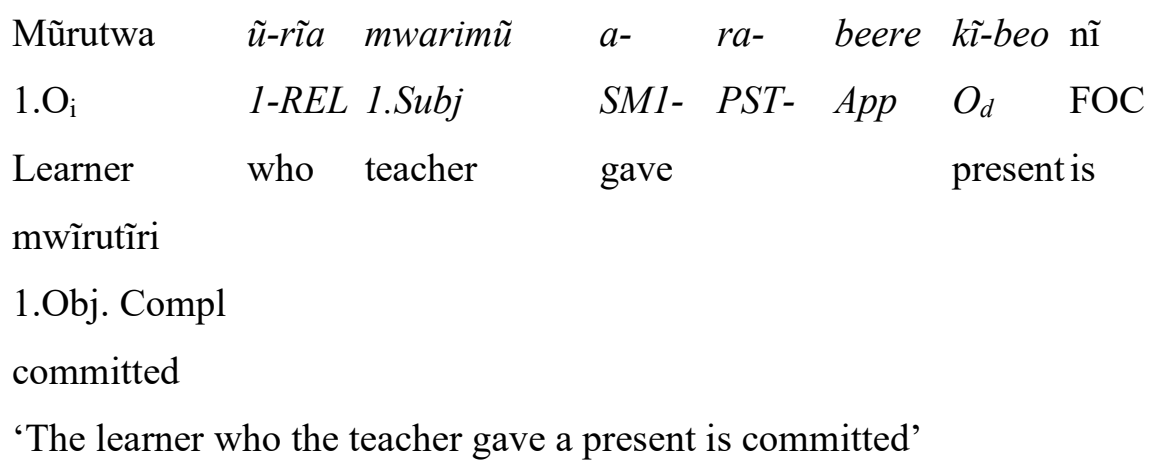

According to Zeller (2004), Tsonga relative clauses forming patterns resemble those of Sotho. While these South African Bantus give a distinction between direct and indirect relative clauses, Kimbeere does not have such distinctions. Both direct and indirect Kimbeere relatives behave in an almost similar manner. Only the position from which the head noun is 
raised differs. Mostly this head noun is first raised to the SpecCP and finally to $\mathrm{D}^{\circ}$. Consider the Tsonga examples of direct and indirect constructions in (17) \& (18) respectively.

(17) munhu loyi afambaka

munhu [loyi a- famba-ka

person $1 \quad$ REL1 Sp- travel- Rs

'a person who travels'

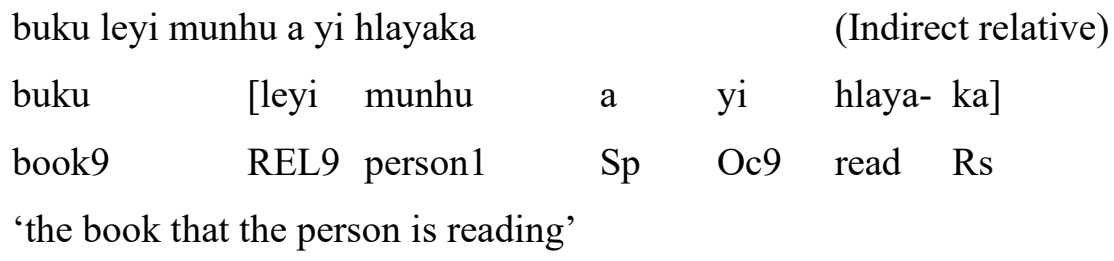

Evidently, the verb in relative clauses in Tsonga is in the participial form and is modified with a relative suffix (-ka). The head noun is represented inside the relative clause through a pronominal clitic (or the subject prefix marked Sp) and through a relative marker. Note how the head noun and the relative marker agree in class and number in a similar manner observable in structure (17). This study found a contrast between direct and indirect relative clauses necessary because noun agreements for objects and subjects differ as is observable in examples (17) and (18). Note that the affix '-yi' is common in both examples. It can then be concluded that '-yi' is the relative marker while 'lo-' and 'le-' are the subject and object markers in (17) and (18) respectively. Apparently, the subject 'munhu' (person) agrees in class and number with 'loyi'. They are all marked 1 meaning they are in noun class 1 and singular in number. Similarly, the object 'buku' (book) agrees with 'leyi' as they are all in noun class 9 and in singular.

The head noun of a relative clause can also be an adjunct. An adjunct is a dispensable phrase in a clause or sentence that amplifies its meaning. Consider sentence (19).

(19) Kĩroko kĩrĩa kwaurire mũno.

Kĩroko kĩ-rĩa kũ- a- ur- ir- e mũno

7.morning 7-REL sm3- PST- rain- PERF- FV very

'in the morning when it rained heavily' 
In (19), 'kiroko' (in the morning) is an adjunct which functions as the head of the relative clause. This sub-classification helped in demonstrating how an adjunct can be a head noun in a Kimbeere relative clause.

\subsection{Headless/Free Relative Clauses}

Headless relative clauses resemble free relative clauses in all aspects. Morphologically the head noun is missing. Semantically and syntactically, this head noun is assumed to be within the relative pronoun. Consider (20) for clarification.

(20) Kĩria gĩaku nĩ gĩaku.

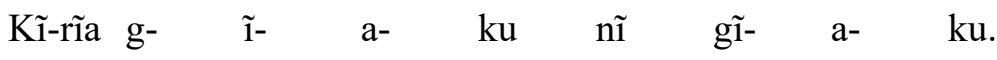

7-REL 7- FOC- POSS 2sg FOC 7- POSS 2sg

'What is yours is yours'

Evidently, there is no noun before the relativizer 'kĩrĩa' (what). This relative pronoun therefore doubles as the head noun also. The clause is thus headless. More examples are in (21) \& (22).

(21) (Wa) Ũrĩa ũgaũka nĩ mwamũkĩre.

(Wa) ũ-rĩa ũ- ga- ũka nĩ mũ- amũk-

(Any) 1.REL sm $1^{-}$FUT- come FOC sm $_{1-}^{-}$welcome- Appl- FV

'Whoever comes is welcome'

(22) (Wa) kĩrĩa tũkethĩrĩria nĩkĩo tũrarathimĩrĩtwe.

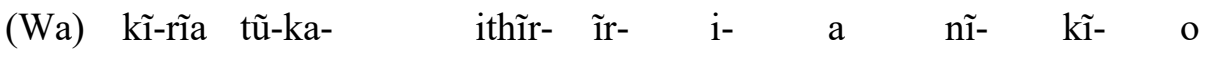

(Any) 7-REL 1pl-FUT- find- Appl- PART-FV FOC- om7-7.REL

tũ- ra- rathim-ĩr- ĩit- w- e

1pl- PST- bless- Appl PERF- PASS FV

'Whatever we will find is what was destined for us'

Through the classification of headless relatives this study was able to establish that Kimbeere and English headless relative clauses have a similar pattern as is evident in (20) to (22) above.In free relative clauses, the antecedent is fused with the relative marker so it is not visible. Look at (23) \& (24).

(23) Nĩ niĩ mbĩcĩ kĩrĩa nonire.

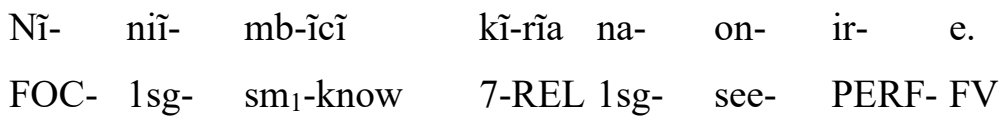


'I only know what I saw'

(24) (Wa) ũrĩa gũkathiĩ gũtirĩ ũkarũmbũyia.

(Wa) ũ-rĩa gũ- ka- thĩ̃ gũ- tirĩ ũ- ka-

(Any) 14-REL 14- FUT- happen sm $_{1-}$ NEG 1- FUT-

rũmbũyia

cares

'(Any) Whatever will happenno one cares'

In (23) for example 'kĩ' in 'kĩrĩa' could mean any noun that agrees in class and number with it (noun marker). Such nouns could be 'kindũ ' (something), 'kĩratũ' (shoe); so that we would end up with structures like 'kĩndũ kĩrĩa' and 'kĩratũ kĩrĩa'. Similarly in (24), ' $\tilde{u}$ ' in 'ũrĩa' could refer to 'ündũ' (something) which would result to 'ündũurria' (something which). From the classification of free relatives this study established that in certain Kimbeere relative clauses head nouns are fused in relative pronouns.

\subsection{Tenseless Relative Clauses}

Jang (2009) makes a distinction between tensed and tenseless relative clauses (infinitival relative clauses). He says that tenseless relative clauses behave almost in a different way as the tensed ones. According to him, infinitival clauses are not full-fledged clauses in the sense that they have no tense. On the other hand, tensed relative clauses have tense markers. Compare the bracketed structures in (25a) \& (25b).

(25)a) I found [a book which you can read].

(Tensed)

(b) I found [a book for you to read].

(Tenseless)

(Jang, 2009)

We can contrast Kimbeere tensed and tenseless relative clauses as in examples (26) \& (27). Note that the head noun and the relative clause are in square brackets.

(26) Nĩngũretere [matumbĩ marĩa ũgakunĩkĩrithia].

(Tensed)

Nĩ- ngũ- ret- ere matumbĩ ma-rĩa ũ- ga-kunĩkĩrithia

FOC- 1sg- bring- for 6.eggs 6-REL 2sg- FUT- incubate

I brought for you eggs which you will incubate

'I brought you the eggs which you will incubate'

(27) Nĩngũretere [matumbĩ ma gũkunîkirithia].

(Tenseless) 
Nĩ- ngũ- ret- ere matumbĩ ma gũ- kunĩkĩrithia

FOC- 2sg- bring- for 6.eggs om6 to- incubate

'I brought for you eggs to incubate'

Note that while (26) has a tense marker within the dependent (relative) clause, (27) does not have such a marker. Sentence (27) also does not have a relative marker. It occurs in form of a to-infinitive. 'To' in such structures appears either as ' $g \tilde{u}$ ' or ' $k \tilde{u}$ ' depending on the head noun for agreement's sake. It would be ungrammatical to write sentence (27) as (28) since a 'toinfinitive' cannot appear in the same construction with a relative marker, in this case 'maria'. Compare the two.

*Nĩngũretere [matumbĩ marĩa ma gũkunĩkĩrithia].

Nĩ- ngũ- ret- ere matumbĩ ma-rĩa ma gũ-kunĩkĩrithia

FOC- 2sg- bring- for 6.eggs 6-REL om 6 to-incubate

(Tenseless)

*'I brought for you eggs which to incubate'

The tenseless relative clauses classification was important to this study because it provided an avenue for comparing tenseless and tensed relative clauses. This study considers all the other types of Kimbeere relative clauses (restrictive, appositive, direct, indirect, free/headless and 'ingĩ') tensed since they have tense markers.

\section{7 '-Ĩngi’’ Relative Clauses}

This study has identified another type of relative clause called '-ingĩ' relative clauses. The clause is introduced by an indefinite pronoun '(î) $\tilde{i}$ gĩ ' translated in English as 'another'. Just like the '-rĩa' relatives (those that have '-rĩa' as the relative marker) '-ingĩ' relatives describe nouns or noun phrases. Compare (29) \& (30).

\begin{tabular}{|c|c|c|c|c|c|c|}
\hline \multicolumn{4}{|c|}{ Gacaũ karĩa Njuki aracaragia nîkoneka. } & \multicolumn{3}{|c|}{ ('-rĩa' Relative) } \\
\hline Gacaũ & ka-rĩa & Njuki & a- & ra- & car- & ag- i- \\
\hline 12.Calf & 12-REL & 1.Njuki & $\mathrm{sm}_{1}$ & PST & look- & HAB-Tra \\
\hline nĩ- & ka- & ek- & & & & \\
\hline FOC- & om $_{12-}$ find- & StP- $\quad F V$ & & & & \\
\hline
\end{tabular}

'The calf which Njuki was looking for has been found'

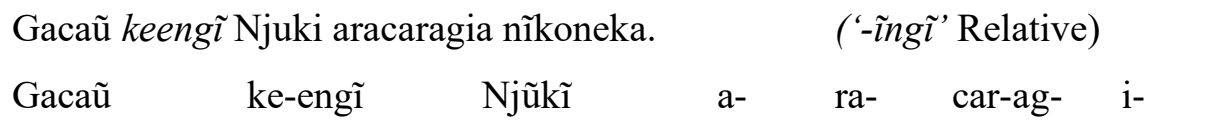




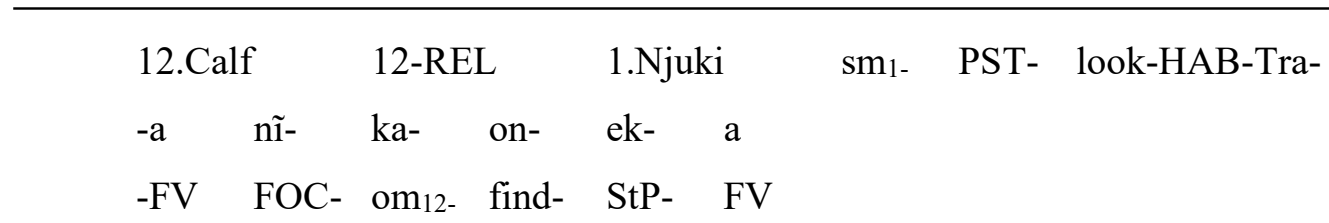

'Another calf Njuki was looking for has been found'

In (29) \& (30), it is evident that the relative clauses 'karia Njuki aracaragia' (which Njuki was looking for) and 'keengĩ Njuki aracaragia' (another Njuki was looking for) both modify/describe the head noun 'gacaũ' (calf). For both '-rĩa' and '-ingĩ' relatives, the head noun agrees in class and number with the noun agreement marker attached to the relative

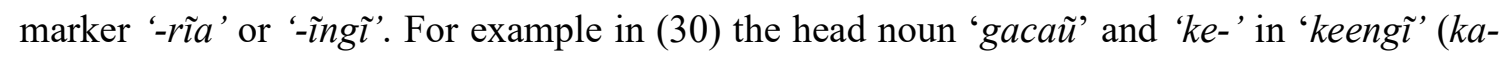
ingĩ) are both in class 12 and also singular. Similarly in (29), 'gacaũ' and 'ka-' in 'karĩa' agree because they are all in class 12 and in singular. However, the two sentences differ in meaning. While 'gacaũ karĩa' (calf which) means a certain calf, 'gacaũ keengĩ' (calf another) refers to an additional calf being described by the relative clause.

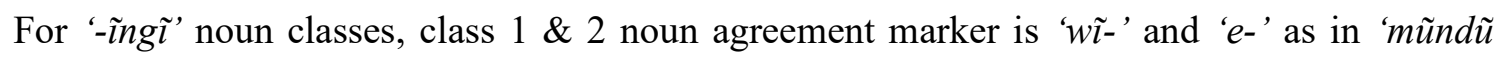

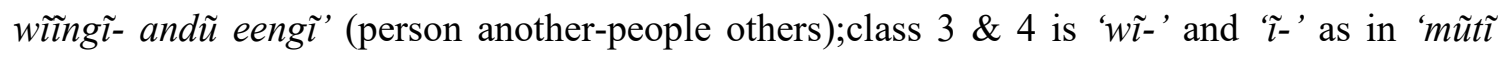
wĩngĩ- mĩtĩ ĩngi' (tree another- trees others); class $5 \& 6$ is 'rĩ-' and 'me-'as in 'ĩrigũ rĩngimarigũ meengĩ' (banana another-banana others); class $7 \& 8$ is 'kĩ-' and 'ci-' as in 'kĩondo kĩngĩ- ciondo ciĩngĩ' (basket another- basket others); class $9 \& 10$ is 'ĩ-' and 'ci-' as in 'ngitĩ

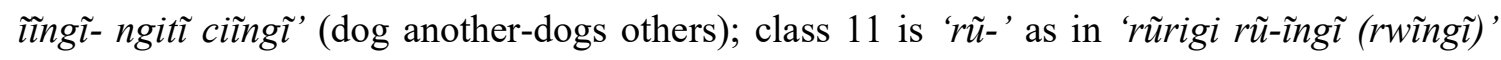
(string another); the plural for class 11 is class 10, that is 'ci-' thus 'ndigi ciinngĩ' (strings others); class $12 \& 13$ is 'ke-' (kae) and 'twĩ-' (tũ̃) as in 'kanya keengĩ- tũnya twĩnngĩ' (gourd

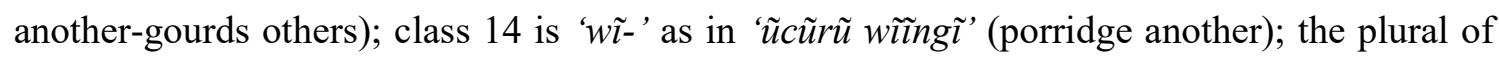
class 14 is 'me-' as in 'macũrũ meengĩ' (porridges others); class 15 is 'kwĩ-' (kũu) as in 'kũgũrũ kwĩngĩ (kũingĩ)' (leg another); class 16 is 'be-'(baĩ) as in 'baandũ beengĩ (baĩngĩ)' (place another). Table 1.1 summarizes Kimbeere noun classes and their '-ingĩ' forms. 
Table 1.1

Kimbeere '-Ĩngĩ' Noun Classes

\begin{tabular}{|c|c|c|c|}
\hline$\overline{\text { Class }}$ & Noun & '-ĩngĩ' Form & Translation \\
\hline 1 & mũndũ & wĩ̄ngĩ & person another \\
\hline 2 & andũ & eengĩ & people others \\
\hline 3 & mũtĩ & wĩ̄ngĩ & tree another \\
\hline 4 & mĩtĩ & ก̃ingĩ & trees others \\
\hline 5 & ĩrigũ & rĩingĩ & banana another \\
\hline 6 & marigũ & meengĩ & bananas others \\
\hline 7 & kĩondo & kĩingĩ & basket another \\
\hline 8 & ciondo & ciĩngĩ & basket others \\
\hline 9 & ngitĩ & ĩngĩ & dog another \\
\hline 10 & ngitĩ & ciîngĩ & dogs others \\
\hline 11 & rũrigi & rwĩngĩ & string another \\
\hline 10 & ndigi & ciĩngĩ & strings others \\
\hline 12 & kanya & keengĩ & gourd another \\
\hline 13 & tũnya & twĩingĩ & gourds others \\
\hline 14 & ũcũrũ & wĩ̄ngĩ & porridge another \\
\hline 6 & macũrũ & meengĩ & porridges others \\
\hline 15 & kũgũrũ & kwĩingĩ & leg another \\
\hline 6 & magũrũ & meengĩ & legs others \\
\hline $15 \mathrm{~A}$ & Kũrĩa & kwĩ̄ngĩ (Infinitive used as noun) & eating another \\
\hline 16 & bandũ & beengĩ (Locative) & place another \\
\hline $15 B$ & kũndũ & kwĩnngì (Locative) & places others \\
\hline
\end{tabular}

The 'Ingĩ' relative clause resembles Kiswahili structures. In Kiswahili, '-ingine' is an adjective that is used to mean 'some', 'different from', 'extra' or 'in place of' (Mvati, Maina $\&$ Kanuri, 2014). Structures (31) to (33) are Kiswahili examples conveying the meanings of 'ingine' highlighted.

(31) Mafuta ya kampuni nyingine yameshuka bei.(zaidi ya, baadhi ya, tofauti na)

Oil of company another has fallen price. (extra,some, different from)

Mafutaya kampuni ny-ingine ya- me shuka bei

6.oil of 4.company 4-REL $\mathrm{sm}_{6-}$ AUX fall 4.price

'Another company's oil's price has fallen'

(32) Wanafunzi wengine wameondoka. (zaidi ya, baadhi ya)

Students others have left. (extra, some)

Wanafunzi we-ngine wa- me- ondoka

2.students 2-REL $\quad \mathrm{sm}_{2}-$ AUX- leave

'Other students have left' 
(33) Duka hilo lingine linauza unga kwa bei ghali. (badala ya)

Shop that another is selling flour at price high. (in place of)

Duka hilo li-ngine li-na- uza unga kwa bei ghali

5.shop that 5-REL $\quad \mathrm{sm}_{5} \mathrm{AUX}$-sell 3.flour at 4.price high

'That other shop is selling flour at a high price'

(Ipara, Burudi \& Wakio, 2010)

The Kimbeere '-ingĩ' relative clause differs from other Kimbeere relative clause types in that it takes a different form. While othertypes take '-rĩa' as the relative marker, '-ingi' relative clause takes the marker '-ing $\tilde{\imath}$ ' as its name suggests. Variations arise only as a result of change

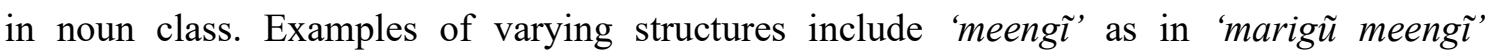
(bananas others), 'eengĩ' as in 'andũ eengĩ' (people others), and 'iĩngĩ' as in 'ndigi ciĩngĩ' (strings others). This classification was important in that it provides variation in relativization of head nouns in Kimbeere relative clauses.

\section{Summary of Research Findings}

This study has established that:

- Kimbeere has seven types of relative clauses. These are: restrictive, appositive, direct, indirect, headless/free, tenseless and '-ingĩ' relative clauses.

- The head noun of a relative clause can be a subject, object (direct or indirect) or an adjunct.

- In Kimbeere, the relative markers are '-rĩa' and '-ĩngĩ' which are usually attached to the head noun marker. These relative markers and head noun markers agree with each other in class and number.

\section{Conclusion}

This paper has shown that Kimbeere has seven types of relative clauses namely restrictive, appositive, direct, indirect, headless/Free, tenseless and '-ĩngĩ' relative clauses.

\section{REFERENCES}

Finegan, E. (2008). Language: Its Structure and Use. Boston: Thomson Wadsworth.

Ipara, I., Burudi, J., Wakio, N. (2010). Upeo wa Sarufi. Oxford University Press East Africa Ltd. Kenya. 
Jang, Y. (2009). Infinitival Relative Clauses in English. English Language and Linguistics 28. Chung-Ang University, 137-155.

Mvati, M., Maina, R., Kanuri, J. (2014). Miale ya Sarufi. The National Education Services. The Franciscan Kolbe Press.

Vries, M. (2002). The syntax of relativization. Doctoral Dissertation, University of Amsterdam. LOT Utrecht.

Zeller, J. (2004). Relative Clause Formation in the Bantu Languages of South Africa. Linguistics Programme. Faculty of Human Sciences.University of KwaZulu-Natal: King George V Avenue, Durban 404, 76-93. 